\title{
New record, host and localities of bat mite of genus Chirnyssoides (Acari, Sarcoptiformes, Sarcoptidae)
}

\author{
Novo registro, hospedeiros e localidades do ácaro de morcego do
} gênero Chirnyssoides (Acari, Sarcoptiformes, Sarcoptidae)

Elizabete Captivo Lourenço ${ }^{1 *}$; Michele da Costa Pinheiro ${ }^{1}$; João Luis Horácio Faccini ${ }^{2}$; Kátia Maria Famadas ${ }^{1}$

\author{
${ }^{1}$ Laboratório de Morfofisiologia de Ácaros, Departamento de Parasitologia Animal, Instituto de Veterinária, \\ Universidade Federal Rural do Rio de Janeiro - UFRRJ, Seropédica, RJ, Brasil \\ ${ }^{2}$ Laboratório de Ixodologia, Departamento de Parasitologia Animal, Instituto de Veterinária, \\ Universidade Federal Rural do Rio de Janeiro - UFRRJ, Seropédica, RJ, Brasil
}

Received October 2, 2012

Accepted May 2, 2013

\begin{abstract}
Chirnyssoides parasitizes the anterior and posterior edges of bat wing membranes. Possibly due to a lack of studies, its distribution is believed to be restricted to a few countries of Central and South America, but its actual range is probably wider. The purpose of this paper is to report the presence of Chirnyssoides amazonae on the bat Carollia perspicillata in the state of Rio de Janeiro, Brazil, and to present a checklist of hosts and localities for Chirnyssoides. Eleven females and 22 egg clusters of $C$. amazonae were collected from 11 individuals of $C$. perspicillata captured in Tinguá Biological Reserve using mist nets. Our search of the literature came up with 69 records of Chirnyssoides. There are reports of Chirnyssoides caparti, Chirnyssoides amazonae, Chirnyssoides brasiliensis and Chirnyssoides phyllostomus in Brazil. This paper reports the first record of Chirnyssoides amazonae in the state of Rio de Janeiro and the second in Brazil, indicating that their known distribution extends to the south. There are records of $C$. amazonae and $C$. surinamensis parasitizing C. perspicillata, but this is the first record of C. amazonae on C. perspicillata in Brazil.
\end{abstract}

Keywords: Carollia perspicillata, Chiroptera, Chirnyssoides amazonae Fain 1959, Chirnyssoides carolliae Fain 1962 , bat ectoparasites.

\section{Resumo}

Chirnyssoides está associado às bordas anteriores e posteriores das membranas das asas de morcegos. Sua distribuição é restrita a alguns países da América Central e do Sul, principalmente devido à falta de estudos. O objetivo deste trabalho foi registrar Chirnyssoides amazonae em Carollia perspicillata no Estado do Rio de Janeiro, bem como apresentar uma lista de hospedeiros e localidades para Chirnyssoides. Onze fêmeas e 22 aglomerados de ovos de C. amazonae foram colhidos em 11 indivíduos de C. perspicillata capturados na Reserva Biológica do Tinguá, utilizando redes de neblina. Na literatura encontramos 69 registros de Chirnyssoides. Para o Brasil há relatos de Chirnyssoides caparti, Chirnyssoides amazonae, Chirnyssoides brasiliensis e Chirnyssoides phyllostomus. Este estudo relata o primeiro registro de Chirnyssoides amazonae no Rio de Janeiro e o segundo para o Brasil expandindo sua distribuição para o sul. Em C. perspicillata há registros de $C$. amazonae e $C$. surinamensis, sendo o primeiro registro de $C$. amazonae em $C$. perspicillata no Brasil.

Palavras-chaves: Carollia perspicillata, Chiroptera, Chirnyssoides amazonae Fain 1959, Chirnyssoides carolliae Fain 1962, ectoparasitos de morcegos.

\footnotetext{
*Corresponding author: Elizabete Captivo Lourenço

Laboratório de Morfofisiologia de Ácaros, Departamento de Parasitologia

Animal, Instituto de Veterinária, Universidade Federal Rural do Rio de

Janeiro - UFRRJ, BR-465, Km 07, CEP 23890-000, Seropédica, RJ, Brasil

e-mail: beteclouren1205@yahoo.com.br
} 


\section{Introduction}

Chirnyssoides Fain 1959 is a genus of the family Sarcoptidae associated with the anterior and posterior edges of bat wing membranes (FAIN; LUKOSCHUS, 1971), which parasitize exclusively Phyllostomidae and Noctilionidae. Currently, there are ten known species, Chirnyssoides amazonae Fain 1959, Chirnyssoides brasiliensis Fain 1959, Chirnyssoides caparti Fain 1959, Chirnyssoides noctilionis (DUSBABEK, 1970), Chirnyssoides parvisuctus Fain and Lukoschus 1975, Chirnyssoides phyllostomus Fain and Lukoschus 1975, Chirnyssoides surinamensis Fain and Lukoschus 1971, Chirnyssoides stenoderma Fain and Lukoschus 1975, Chirnyssoides vampyrops Fain and Lukoschus 1975, and Chirnyssoides venezuelae Fain 1959.

The known distribution of Chirnyssoides is restricted to a few Central and South American countries (FAIN, 1959, 1960, 1962; FAIN; LUKOSCHUS, 1971, 1975; WEBB; LOOMIS, 1977; KLOMPEN, 1992), probably due to lack of research. Most studies are limited to the description of species (FAIN, 1959, 1962; FAIN; LUKOSCHUS, 1971, 1975). The most recent study, conducted by Klompen (1992), emphasizes the phylogeny of sarcoptic mites, providing several new records and a dichotomous key for Chirnyssoides species. The purpose of this paper is to record C. amazonae parasitizing Carollia perspicillata (Linnaeus 1758) in the state of Rio de Janeiro, southeast Brazil, and to present a checklist of hosts and localities for Chirnyssoides.

\section{Materials and Methods}

Fifty-six individuals of $C$. perspicillata were captured with mist nests and released after examination between June and December 2011 at Tinguá Biological Reserve (22 34' 57.4' S and $043^{\circ} 26^{\prime}$ 15.9” W) in the state of Rio de Janeiro, according to protocol no. 010859/2011 approved by the Animal Ethics Committee of Federal Rural University of Rio de Janeiro. The mites were removed from the wings with forceps and placed in microtubes with $70 \%$ ethanol. One of the parasitized bats was euthanized (according to resolution 714 of the Federal Council for Veterinarian Medicine, June 20, 2002), fixed in $10 \%$ formalin and preserved in $70 \%$ ethanol for laboratory observation of the mites attached to the bat's wings. The specimens were then cleared with lactic acid and mounted in Hoyer's medium.

Imaging and measurements were performed at the Laboratory of Microscopy and Bioimaging, Department of Animal Parasitology, Federal Rural University of Rio de Janeiro, using an Olympus UC30 optical microscope equipped with Differential Interference Contrast, an Olympus SZX16 stereoscopic microscope, and the CELL imaging program. The specimens were identified according to Fain (1959), Fain and Lukoschus (1975) and Klompen (1992). Bat nomenclature was based on Gardner (2008) and mite nomenclature on Klompen (1992).

\section{Results}

A total of 11 females (Figures $1 \mathrm{~A}$ and B) and 22 egg clusters (Figures 1C and D) of mites were collected from 11 C. perspicillata in Rio de Janeiro. The maximum intensity of egg clusters and mites observed on one bat was six and three, respectively. The females and eggs are visible to the naked eye as small milky clumps attached to the anterior and posterior edges of bats' wings (Figure 1D). Under the stereomicroscope it was possible to observe the females near the egg clusters, with their ventral aspect facing the skin of host. After clearing, the females were identified by optical microscopy as ovigerous $(\mathrm{n}=3)$ (Figure $1 \mathrm{~A})$ and non-ovigerous $(n=8)$. The presence of the elongated idiosoma, eight pairs of long perianal setae with four anterior filiform pairs and four posterior pairs with inflated base and coxal apodemes III with a bifurcate basal branch (Figure 1B) led us to conclude that the mites are C. amazonae females.

Several egg clusters ranging from three to 42 eggs were observed. Fifty-two (16.3\%) eggs from a total of 320 eggs were observed with larvae enclosed in the egg shell (Figure 1E). The eggs are milky, oblong, with a narrower base that connects to a short stalk (Figure 1F) which is attached to the wings of bats by some sort of cement. In some larvae enclosed in the egg shell, it was possible to observe the characteristics of $C$. amazonae larvae, such as coxal apodemes III with a bifurcate basal branch. A milky filament was visible connecting one cluster of eggs to another (Figure 1D). The origin of this filament could not be verified, but it is similar to the cement found at the base of other egg clusters.

We found 69 records of Chirnyssoides in 10 countries and 30 hosts in the literature (Table 1). Two records are limited to a description of the species C. parvisuctus and C. stenoderma. Surinam and Panama have the highest number of records. In Brazil, there are reports of C. caparti parasitizing Artibeus jamaicensis Leach 1821 in the state of Amazonas, C. amazonae parasitizing Carollia brevicauda (Schinz 1821) in Amazonas, C. brasiliensis parasitizing Sturnira lilium (E. Geoffroy 1810) in the states of Amazonas and Pernambuco, and C. phyllostomus parasitizing Lophostoma carrikeri (Allen 1910) in the state of Pará. The type locality of C. amazonae is Amazonas, and this specimen has been reported to be associated with $C$. brevicauda, the only record of that species in Brazil. There are reports of this species parasitizing $C$. perspicillata in Panama and Surinam. Chirnyssoides amazonae has been recorded in six countries and six hosts. There are records of $C$. amazonae and C. surinamensis parasitizing C. perspicillata (Table 1). This study reports the first record of Chirnyssoides in the state of Rio de Janeiro and the second in Brazil.

\section{Discussion}

Carollia perspicillata is a species of Phyllostomidae widely distributed in the Neotropical region, and has a high capture rate (FLEMING, 1988; CLOUTIER; THOMAS, 1992; BERNARD, 2002). It presents a wide variety of parasites (WEBB; LOOMIS, 1977). Moreover, its behavioral biology favors the presence of ectoparasites because of its fidelity to the roost, such as hollow trees and caves (FLEMING, 1988; PATTERSON et al., 2007). The mites found on C. perspicillata showed diagnostic features of C. amazonae females, and are easily distinguishable from other species of Chirnyssoides (KLOMPEN, 1992).

Fain and Lukoschus (1975) believed that the specimen described as the female holotype of $C$. amazonae is actually a tritonymph of 


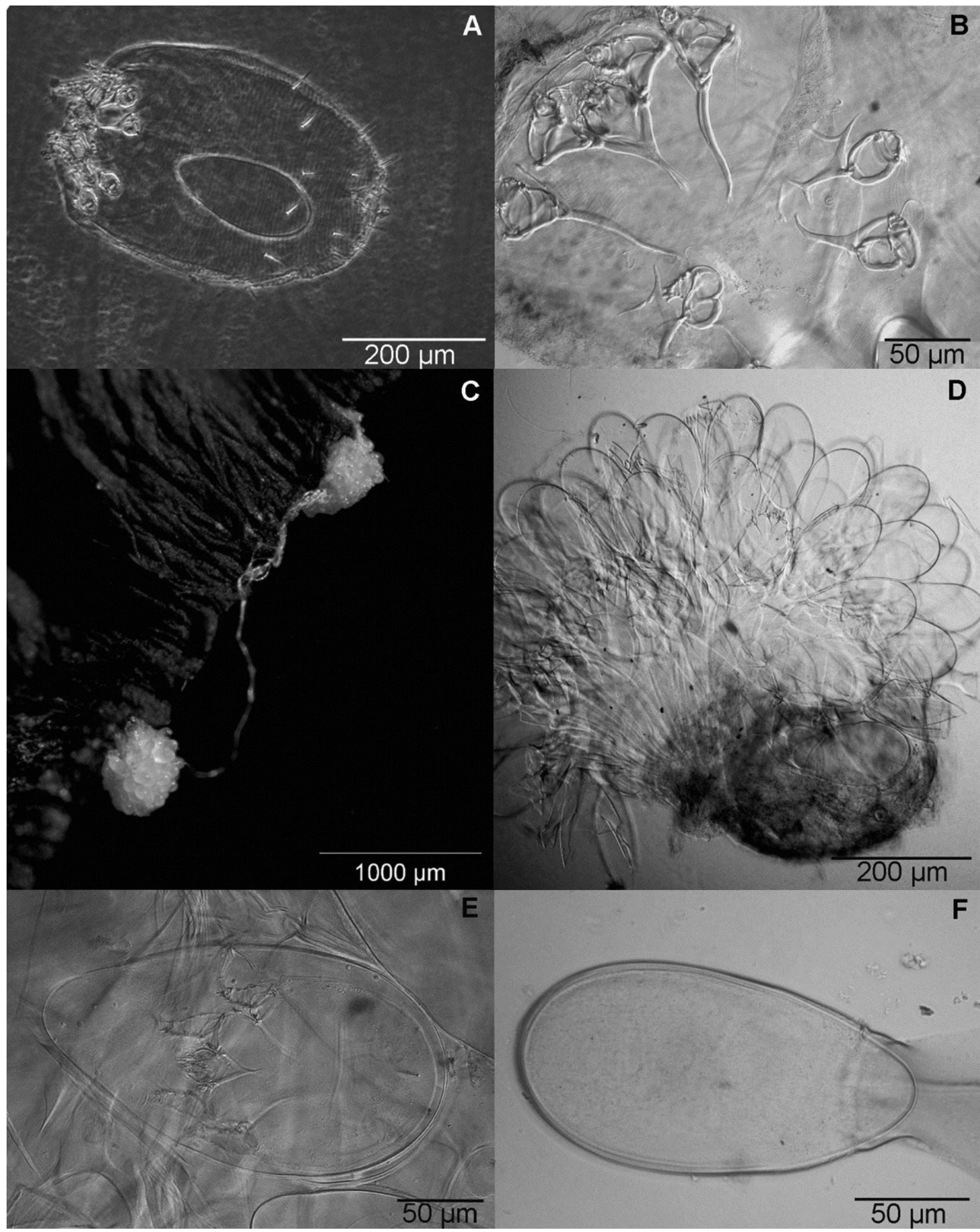

Figure 1. Chirnyssoides amazonae. A, B, D, E, F Photomicrography with Differential Interference Contrast and D with microscope esteroscopic. A- Ovigerous female, B- Ventral view of female showing left apodemes coxal III, C- Two egg groups on wing edges of C. perspicillata (view), D- Egg groups, E- Larvae enclosed in the egg shell, F- Egg and stalk. 
Table 1. Records of host and localities for species of Chirnyssoides.

\begin{tabular}{|c|c|c|}
\hline Parasite & Host & Localities \\
\hline \multicolumn{3}{|c|}{ Chirnyssoides noctilionis (Dusbabek 1970) } \\
\hline & Noctilio leporinus (Linnaeus 1758) & $\mathrm{Cuba}^{\mathrm{d}, \mathrm{e}, \mathrm{f}, \mathrm{h}}$ \\
\hline & Noctilio albiventris Desmarest 1818 & Surinam ${ }^{\mathrm{effh}}$ \\
\hline \multicolumn{3}{|c|}{ Chirnyssoides amazonae Fain 1959} \\
\hline & Carollia brevicauda (Schinz 1821) & Brazil $^{a}$, Ecuador $^{\text {h }}$, Mexico $^{\text {h }}$ \\
\hline & Carollia subrufa (Hahn 1905) & Panamac $^{c}$, Mexico $^{h}$ \\
\hline & Carollia castanea Allen 1890 & Ecuador $^{\mathrm{h}}$ \\
\hline & Carollia perspicillata (Linnaeus 1758) & Panama $^{\mathrm{c}}$, Surinam ${ }^{\mathrm{e}, \mathrm{fh}}$, this paper \\
\hline & Micronycteris megalotis (Gray 1842) & Surinam ${ }^{\mathrm{e}}$ \\
\hline & Glossophaga soricina (Pallas 1766) & Surinam $^{\mathrm{e}, \mathrm{f}}$, Peru $^{\mathrm{h}}$, Mexico $^{\mathrm{h}, \mathrm{f}, \mathrm{d}}$ \\
\hline \multicolumn{3}{|l|}{ Chirnyssoides caparti Fain 1959} \\
\hline & Artibeus jamaicensis Leach 1821 & Brazila, $^{a, g}$, Panama $^{c}$, Mexico $^{\mathrm{g}}$ \\
\hline & Artibeus cinereus (Gervais 1856) & Panama $^{\mathrm{c}}$, Surinam ${ }^{\mathrm{fh}}$ \\
\hline & Artibeus lituratus (Olfers 1818) & Surinam $^{\mathrm{fh}}$, Mexico $^{\mathrm{h}}$, Paraguay ${ }^{\mathrm{h}}$, Peru $^{\mathrm{h}}$ \\
\hline & Artibeus toltecus (Saussure 1860) & Panama $^{\mathrm{c}}$, Mexico $^{\mathrm{g}}$ \\
\hline & Chiroderma salvini Dobson 1878 & Panama $^{c}$ \\
\hline & Desmodus rotundus (E. Geoffroy 1810) & Panama $^{c}$ \\
\hline & Vampyressa pusilla (Wagner 1843) & Panama $^{c}$ \\
\hline & Vampyrodes caraccioli Thomas 1889 & Panama $^{c}$ \\
\hline & Platyrrhinus vittatus (Peters 1860) & Panama $^{c}$ \\
\hline & Uroderma bilobatum Peters 1866 & Surinam ${ }^{\mathrm{f}, \mathrm{h}}$ \\
\hline & Unidentified bat & Dominican Republic ${ }^{\mathrm{b}}$ \\
\hline \multicolumn{3}{|c|}{ Chirnyssoides vampyrops Fain and Lukoschus 1975} \\
\hline & Platyrrhinus helleri (Peters 1866) & Surinam ${ }^{\mathrm{f}}$ \\
\hline & Uroderma bilobatum Peters 1866 & Surinam ${ }^{\mathrm{f}, \mathrm{h}}$ \\
\hline & Platyrrhinus lineatus (E. Geoffroy 1810) & Paraguay $^{\text {h }}$ \\
\hline \multicolumn{3}{|c|}{ Chirnyssoides surinamensis Fain and Lukoschus 1971} \\
\hline & C. perspicillata & Surinam ${ }^{\mathrm{effh}}$, Peru $^{\mathrm{h}}$ \\
\hline & C. brevicauda & Ecuador $^{\text {h }}$, Mexico $^{\text {h}}$, Peru $^{\text {h }}$ \\
\hline & C. subrufa & Mexico $^{\text {h }}$ \\
\hline & G. soricina & Mexico $^{\mathrm{h}}$ \\
\hline \multicolumn{3}{|c|}{ Chirnyssoides stenoderma Fain and Lukoschus 1975} \\
\hline & Pygoderma sp. (Wagner 1843) & Surinam ${ }^{\mathrm{f}}$ \\
\hline \multicolumn{3}{|c|}{ Chirnyssoides parvisuctus Fain and Lukoschus 1975} \\
\hline & Micronycteris brachyotis (Dobson 1878) & Surinam ${ }^{\mathrm{f}, \mathrm{h}}$ \\
\hline & Chirnyssoides brasiliensis Fain 1959 & \\
\hline & Sturnira lilium (E. Geoffroy 1810) & Brazil $^{\mathrm{a}}$, Surinam ${ }^{\mathrm{fhh}}$ \\
\hline & Phylloderma stenops Peters 1865 & Venezuela $^{\text {h }}$ \\
\hline \multicolumn{3}{|c|}{ Chirnyssoides phyllostomus Fain and Lukoschus 1975} \\
\hline & Phyllostomus hastatus (Pallas 1767) & Surinam ${ }^{\mathrm{f}, \mathrm{h}}$ \\
\hline & Lophostoma carrikeri (Allen 1910) & Brazil $^{\mathrm{h}}$ \\
\hline & Lophostoma sivicolum d'Orbigny 1836 & Surinam $^{\mathrm{h}}$ \\
\hline \multicolumn{3}{|c|}{ Chirnyssoides venezuelae Fain 1959} \\
\hline & Lophostoma brasiliense Peters 1867 & Venezuela $^{a}$ \\
\hline & L.sivicolum & Surinam ${ }^{\mathrm{f}, \mathrm{h}}$ \\
\hline
\end{tabular}

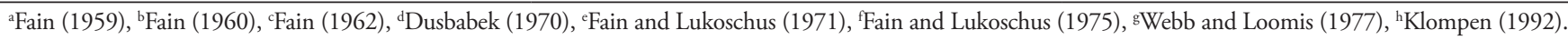

Chirnyssoides carolliae (FAIN 1962) and considered it a synonym of $C$. amazonae. This increased the number of records and of the species' distribution, and expanded the body of knowledge about the morphology of all the life stages of the species (FAIN, 1959; 1962; FAIN; LUKOSCHUS, 1975).

Species of Teinocoptinae Fain, 1959, which includes Chirnyssoides, present a phylogenetic lineage associated with bats, but some groups have evolved, fully or partially, by parasitizing other small mammals, as in the case of Notoedres Railliet, 1893 (KLOMPEN, 1992). Chirnyssoides and Notoedres showed a unique modification in their egg deposition system. The eggs of Chirnyssoides and some species of Notoedres have stalks that anchor them to the skin of the host in clusters, united by the fused bases of the egg stalks (KLOMPEN, 1992). Klompen (1992) suggests that this 
egg deposition system may be linked to their co-evolution with bats, since the stalks are reduced or absent in Notoedres species that parasitize hosts other than bats. This egg deposition system may be an adaptation of mites to prevent the detachment of their eggs during the host's flight.

Egg clusters can be abundant in a host ( $\mathrm{n}=6$, in this study) and easily visible to the naked eye, requiring only a more careful observation of the bat. The handling of the material and its removal from the host should be performed with caution, since the material is delicate, particularly after clearing. Eggs with stalks in clusters provide a clue, facilitating the initial identification under the stereoscopic microscope. This study shows details of Chirnyssoides eggs (Figure 1) not published in the literature.

Only adult females and egg clusters with a few larvae enclosed in egg shells were found in $C$. perspicillata, although $C$. amazonae include larvae, protonymphs, tritonymphs, and female and male adults (FAIN, 1959). Males of some species of Chirnyssoides are unknown or difficult to find, whereas larger numbers of females are more likely to be found (FAIN, 1962). This may be because adult females are found on the egg clusters, which are easily visible because of their larger size. Chirnyssoides amazonae has been found on the anterior and posterior edge and on the surface of the wing (FAIN, 1959; FAIN; LUKOSCHUS, 1971; KLOMPEN, 1992), as was the case in this study. Other species have been reported elsewhere on the body of bats, and $C$. amazonae have also been found. C. caparti females were found partially buried in small horny cuticles, and immature males were found intradermally on the wings of $A$. jamaicensis (FAIN, 1959). Chirnyssoides venezuelae was found on the wings and ear skin of Lophostoma brasiliense Peters 1867 (FAIN, 1959) and C. brasiliensis on the wings and ear skin of S. lilium (FAIN, 1959).

The paucity of records of Chirnyssoides may reflect a lack of studies, but may also be due to the low prevalence of the species. Research into these mites is scanty, mainly because it is difficult to visualize the mites on bats and due to the lack of experts. However, Klompen (1992) expanded the dichotomous key to all the stages of Chirnyssoides species, which makes it easier to study these mites. Even so, few studies have focused on this group and its biology is largely unknown. The species with the highest number of records are those that parasitize more frequently captured bats, such as $C$. perspicillata and $A$. jamaicencis. However, there is a need for much more information on mites of this genus. The relation of specificity of Chirnyssoides to its hosts is also noted, with C. amazonae parasitizing Carollia species and C. caparti parasitizing Stenodermatinae species, such as Artibeus.

This study extends the known distribution of Chirnyssoides in Brazil by including the first record for Rio de Janeiro. Further studies of Chirnyssoides in Brazil will provide a better understanding of their relationship with other bats and their distribution.

\section{Acknowledgements}

We would like to thank FAPERJ that financed the field work and substantial sampling material; to Entidade Ambientalista Onda Verde for logistic support; to SINDIPETRO CAXIAS for lodging; to Gomes, L.A.C., Patrício, P.M.P., Dias, R.M., Dellamare, R. and França Jr, H.M. for field assistance; to Costa-Santolin, I.D.A. for help in performing the microscopy images. To Lourenço, E.C. thanks CNPq and Pinheiro, M.C. thanks Capes for the respective scholarships. License number 28064-2 (SISBIO/ICMBio).

\section{References}

Bernard E. Diet, activity and reproduction of bat species (Mammalia: Chiroptera). Rev Bras Zool 2002; 19(1): 173-188. http://dx.doi. org/10.1590/S0101-81752002000100016

Cloutier D, Thomas DW. Carollia perspicillata. Mammal Species 1992; 417: 1-9.

Dusbabek F. Mites of the genus Notoedres (Acarina: Sarcoptiformes) parasitic on Cuban bats. Folia Parasit 1970; 17: 271-276.

Fain A. Les acariens psoriques parasites des chauves-souris. X. Le genre Chirnyssoides g.n. chez les chauves-souris sud-américaines (Sarcoptiformes: Sarcoptidae). Bull Inst Roy Sci Nat Belg 1959; 35(31): 1-19.

Fain A. Les acariens psoriques parasites des chauves-souris. XV. Notes sur deux sarcoptides américains des genres Chirnyssoides et Notoedres. Bull Ann Soc Roy Entomol Belgique 1960; 96(11-12): 291-292.

Fain A. Les acariens psoriques parasites des chauves-souris. XXII. Especes des genres Chirnyssoides et Notoedres. Bull Ann Soc Roy Entomol Belgique 1962; 98(27): 392-403.

Fain A, Lukoschus FS. Parasitic mites of Surinam. XVIII. Mites of the genera Notoedres and Chirnyssoides from bats (Sarcoptiformes: Sarcoptidae). Bull Ann Soc Roy Entomol Belgique 1971; 107: 298-313.

Fain A, Lukoschus FS. Parasitic mites of Surinam. XXX. New observations on the genera Chirnyssoides and Notoedres from bats (Sarcoptiformes: Sarcoptidae). Acta Zool Pathol Antverp 1975; 61: 91-118.

Fleming TH. The short-tailed fruit bat: a study in plant-animal interactions. Chicago: University of Chicago Press; 1988.

Gardner AL. Mammals of South America, Vol. 1: marsupials, xenarthrans, shrews, and bats. Chicago: University of Chicago Press; 2008.

Klompen JSH. Phylogenetic relationships in the mite family Sarcoptidae (Acari: Astigmata). Michigan: Museum of Zoology, University of Michigan; 1992.

Patterson BD, Dick CW, Dittmar K. Roosting habits of bats effect their parasitism by bat flies (Diptera: Streblidae). J Trop Ecol 2007; 23(2): 177-189. http://dx.doi.org/10.1017/S0266467406003816

Webb JP, Loomis RB. Ectoparasites. In: Baker RJ, Jones JK Jr, Carter DC, editors. Biology of bats of the new world family Phyllostomidae, Part II. Lubbock: Texas Tech University; 1977. p. 57-120. 